\title{
Rozwój kompetencji przedsiębiorczych dzięki nauczaniu z wykorzystaniem wirtualnych gier strategicznych
}

\author{
Aleksandra Gaweł \\ Katedra Konkurencyjności Międzynarodowej, Wydział Gospodarki Międzynarodowej, \\ Uniwersytet Ekonomiczny w Poznaniu
}

\begin{abstract}
Celem artykułu jest ocena możliwości rozwoju kompetencji przedsiębiorczych dzięki wykorzystaniu innowacyjnej metody nauczania w postaci wirtualnej gry strategicznej. W tej metodzie markuje się samodzielne prowadzenie przedsiębiorstwa w środowisku wirtualnym. Osoby uczące się są stawiane w roli przedsiębiorców, zakładają i zarządzają wirtualnymi przedsiębiorstwami, jednocześnie konkurując z pozostałymi graczami. Badanie przeprowadzono wśród studentów z Polski, Finlandii, Hiszpanii i Estonii, którzy uczestniczyli w rozgrywkach wirtualnej gry strategicznej. Po jej zakończeniu, studenci w badaniu ankietowym określili kompetencje, które mogą się rozwinąć w czasie jej trwania. Zdaniem badanych, w największym stopniu dzięki wirtualnym grom strategicznym można rozwinąć zdolności do podejmowania decyzji, umiejętności pracy grupowej i rozwiązywania problemów. Jednak możliwości rozwoju kompetencji zależą od wcześniejszych doświadczeń z wirtualnymi grami edukacyjnymi oraz od bycia z pokolenia cyfrowo urodzonych.
\end{abstract}

Słowa kluczowe: kompetencje przedsiębiorcze, wirtualne gry strategiczne, cyfrowi z urodzenia, edukacja przedsiębiorcza, grywalizacja

\section{Kompetencje przedsiębiorcze $\mathrm{i}$ ich kształtowanie w pokoleniu cyfrowo urodzonych}

Niezależnie od wiary w to, iż przedsiębiorcą człowiek się rodzi bądź też może się nim stać, w ostatnich latach ogromny wysiłek finansowy i organizacyjny jest czyniony w celu zwiększenia skali edukacji przedsiębiorczej (Lans i in., 2008). W dyskusjach podejmuje się wątki związane z treścią programów nauczania, sposobami prowadzenia edukacji, powiązaniami nauczania z praktyką gospodarczą itp. 
Jednakże samo pojęcie i zakres edukacji przedsiębiorczej są w literaturze bardzo rozproszone, gdyż łączy ona dorobek nauk behawioralnych oraz nauk ekonomicznych. Mówi się o trzech wymiarach edukacji przedsiębiorczej: 1) edukacji o przedsiębiorczości, obejmującej wiedzę o zakładaniu i prowadzeniu własnego przedsiębiorstwa, 2) edukacji dla przedsiębiorczości, kształtującej umiejętności niezbędne do prowadzenia własnej działalności gospodarczej oraz 3) edukacji przez przedsiębiorczość, pomagającej rozwijać dalsze umiejętności biznesowe na rzecz już działających przedsiębiorców (Wach, 2016). W innym ujęciu uważa się, że edukacja przedsiębiorcza, oprócz rozumienia istoty przedsiębiorczości, powinna być nakierowana na stawanie się osobą przedsiębiorczą, czyli osobą mającą cechy przedsiębiorcze, oraz na stawanie się przedsiębiorcą, czyli osobą zakładającą i prowadzącą własną firmę (Heinonen, Poikkijoki, 2006).

W dyskusji na temat edukacji przedsiębiorczej interesujące wydaje się jednak podejście od strony kompetencji, które należy kształcić w procesie nauczania. Kompetencje są tłumaczone jako szeroko rozumiane cechy osobowe konieczne do lepszego zachowania, przy czym dwa główne nurty badań kompetencji wydają się być najbardziej znaczące. Pierwszym z nich jest podejście behawioralne, zorientowane na pracownika, w którym podchodzi się do kompetencji posiadanych przez daną osobą niezależnie od kontekstu zawodowego, w którym działa. Drugim jest podejście funkcjonalne, skoncentrowane na pracy, w którym kompetencje analizuje się w odniesieniu do kontekstu wykonywanej pracy (Lans $\mathrm{i}$ in., 2008).

Kompetencje przedsiębiorcze można wąsko rozumieć jako efektywny sposób, by połączyć wiedzę, umiejętności i postawy potrzebne do stworzenia nowego przedsięwzięcia. W takim ujęciu, kompetencje przedsiębiorcze są nieuchwytne, są jednak związane $z$ odkrywaniem i rozwojem możliwości biznesowych oraz pozyskiwaniem zasobów, by wdrożyć te możliwości w celu uruchomienia nowego przedsięwzięcia (Rasmussen, Mosey, Wright, 2015). Innym podejściem jest szerokie rozumienie kompetencji przedsiębiorczych, związane z charakterystyką osób przedsiębiorczych. Kompetencje te można podzielić na trzy grupy: 1) kompetencje osobowościowe, umożliwiające skutecznej funkcjonowanie w różnych sytuacjach, 2) kompetencje osobiste, określane również jako behawioralne, oraz 3) kompetencje menedżerskie, związane $\mathrm{z}$ zarządzaniem pracownikami lub współpracą w zespole (Piróg, 2015).

Interesującą koncepcję zaproponowała T. Boyles (2012), w której podzieliła kompetencje przedsiębiorcze na trzy grupy: 1) kompetencje poznawcze, 2) kompetencje społeczne i 3) kompetencje zorientowane na działanie. Kompetencje te powiązała z kompetencjami istotnymi w XXI w., które wskazuje się jako kluczowe umiejętności, wiedzę i postawy istotne do kształtowania wśród studentów, do których zalicza: 1) informację, media i sprawność technologiczną, 2) pomysłowe 
myślenie, 3) komunikację i współpracę oraz 4) produktywność i pozyskiwanie zasobów. Zdaniem tej autorki, w dużej mierze kompetencje XXI w. „zachodzą” na kompetencje przedsiębiorcze. Kompetencje związane $\mathrm{z}$ informacjami, mediami i sprawnością technologiczną oraz twórcze myślenie odpowiadają poznawczym kompetencjom przedsiębiorczym. Kompetencje XXI w. w zakresie komunikacji i współpracy są powiązane ze społecznymi kompetencjami przedsiębiorczymi, zaś kompetencje przedsiębiorcze zorientowane na działanie mogą być utożsamiane z produktywnością i pozyskiwaniem zasobów jako kompetencjami XXI w. (zob. rysunek 1).

W toku dyskusji na temat kompetencji przedsiębiorczych kształtowanych $\mathrm{w}$ trakcie procesu edukacji istotną kwestią jest nie tylko zestaw owych kompetencji, lecz także skuteczność nauczania. Ta natomiast zależy od efektywności metod dydaktycznych, które powinny być wdrażane w zależności od indywidualnych predyspozycji osoby uczącej się. Współcześnie podstawową koncepcją pedagogiczną jest paradygmat konstruktywistyczny, stawiający studenta i jego aktywność w centrum procesu dydaktycznego. Paradygmat ten zakłada, że uczenie się jest aktywnym procesem, polegającym na indywidualnym konstruowaniu schematów poznawczych, ich przebudowywaniu oraz włączaniu w istniejące już struktury wiedzy (Gaweł, Wach-Kąkolewicz, 2016).

By skutecznie móc wdrożyć paradygmat konstruktywistyczny do edukacji przedsiębiorczej, należy zidentyfikować i scharakteryzować współczesnego uczącego się, ze szczególnym uwzględnieniem jego percepcji i preferowanych styli uczenia się.

M. Prensky (2001) stworzył koncepcję dwóch generacji uczących się: cyfrowych z urodzenia (digital natives) oraz cyfrowych z przyuczenia, zwanych również cyfrowymi imigrantami (digital immigrants). M. Kąkolewicz (2011, s. 27 i nast.) proponuje również dodanie do tego podziału cyfrowych ignorantów (digital ignoramuses), którzy odrzucają stosowanie technologii cyfrowych.

Osoby cyfrowe $\mathrm{z}$ urodzenia wzrastają w cyfrowym środowisku, gdzie dostęp do informacji jest interaktywny, informacje można pozyskać natychmiastowo, a dodatkowo wykorzystuje się urządzenia mobilne zamiast komputerów (Kirk i in., 2015). Są połączeni ze sobą dzięki wykorzystaniu urządzeń cyfrowych oraz uważani za generację, która jest wielozadaniowa i uczy się w szybkim tempie (Neumann, 2016). Cyfrowi z urodzenia przy uczeniu się dążą do szybkiego zdobywania informacji z różnych źródeł multimedialnych, najpierw korzystają z obrazu, koloru, dźwięku, a potem dopiero z tekstu, bazują na przypadkowym dostępie do zróżnicowanych źródeł multimedialnych, współpracują, komunikują się w grupach (Prensky, 2001). Dodatkowo, uczą się oni „just in time”, oczekują natychmiastowej gratyfikacji w postaci różnych nagród, uczą się tego, co w ich odbiorze jest lub wydaje się być istotne, aktywne, użyteczne i zabawne. 
Osoby cyfrowe z przyuczenia w czasie procesu uczenia się wykorzystują ograniczone źródła wiedzy, w tym głównie tekst, cechują się myśleniem sekwencyjnym i rozwiązywaniem pojedynczych zadań. Dążą raczej do interakcji z pojedynczą osobą niż z grupą osób.

W opinii M. Prensky'ego (2001), za cyfrowych z urodzenia należy uznać wszystkie osoby urodzone po 1980 r., jednakże ze względu na znaczący postęp w dostępie i sposobie użytkowania technologii ICT należy wskazać na występowanie dwóch generacji cyfrowych $z$ urodzenia. Zgodnie $z$ ujęciem R. Joinera i in. (2013), można przyjąć, iż pierwsza z generacji cyfrowych przyszła na świat po 1980 r., natomiast druga po 1993 r. Zgodnie z ich badaniami, występują znaczące różnice w postawie i stopniu wykorzystania Internetu obu generacji, przy czym druga z nich użytkuje Internet częściej i z lepszym nastawieniem.

Choć koncepcja generacji cyfrowych uczących się zyskuje wielu zwolenników, nie brak również głosów krytycznych. Można także spotkać w literaturze zdania, że brakuje dowodów, by współczesne pokolenie studentów wykorzystywała znacząco inny styl uczenia wynikający ze skomplikowanych technologii. W istocie, postawy studentów wobec uczenia się wydają się bardziej wynikać z metod nauczania wykorzystywanych przez nauczycieli (Chaves, Maia Filho, Melo, 2016).

Uważa się, że choć pokolenie cyfrowych z urodzenia jest zaznajomiona z technologiami ICT, nie zawsze potrafi jej dobrze używać. Cyfrowi z urodzenia mają wysokie oczekiwania wobec technologii, ale nie zawsze rozumieją jej ograniczenia (Neumann, 2016). Dodatkowo, pokolenie to nie jest homogeniczne pod względem wykorzystania nowych technologii i można spotkać znaczące różnice w podejściu do ICT w ramach tej grupy (Chaves, Maia Filho, Melo, 2016).

\section{Istota wirtualnych gier strategicznych jako narzędzia edukacyjnego}

Ponieważ proces uczenia się jest kompleksowym zadaniem poznawczym, stąd też jednym $z$ obszarów dyskusji są metody nauczania i ocena ich efektywności. Tradycyjne nauczanie ex cathedra przestało być jedyną metodą, a charakterystyka osób cyfrowych z urodzenia i ich sposobu uczenia się wskazuje, że metoda ta raczej nie znajdzie wielkiego uznania u dzisiejszych studentów.

Przede wszystkim uważa się, że metody stosowane w edukacji przedsiębiorczej powinny bazować na rozwiązywaniu problemów i zawierać elementy learning-by-doing (Tan, Ng, 2006), powinny nie tylko dostarczać wiedzę, lecz także rozwijać nowe sposoby myślenia, nowe zdolności i sposoby zachowań (Heinonen, 
Poikkijoki, 2006) oraz angażować studentów w proces uczenia (Balan, Metcalfe, 2012).

Metodą dydaktyczną spełniającą przedstawione założenia wydaje się być metoda wirtualnych gier strategicznych (Gaweł, Wach-Kąkolewicz, 2016). Wprawdzie tradycyjne nauczanie $z$ wykorzystaniem wykładów i prac projektowych nadal dominuje na uczelniach, jednak cyfrowa edukacja z komputerowymi grami symulacyjnymi zyskuje coraz większą popularność jako komplementarna alternatywa dla tradycyjnych metod. Komputerowe gry symulacyjne wspierają tradycyjne nauczanie poprzez wprowadzenie do edukacji aspektów realnego życia oraz dzięki udzielaniu uczącym się natychmiastowej informacji zwrotnej dotyczącej podjętych przez nich decyzji (Sørebø, Hæhre, 2012).

Gry edukacyjne są definiowane jako metoda, w której uczący się biorą udział w aktywnościach z założonymi zasadami postępowania, jednocześnie ze sobą konkurując. Gry te pozwalają nauczycielom na stworzenie scenariuszy z prawdziwego życia, których rozstrzygnięcie nie ma rzeczywistych konsekwencji. Gry edukacyjne pozwalają studentom na komunikację, współpracę, rozwijają krytyczne myślenie. Jednakże ich efektywność pedagogiczna jest nadal rozstrzygana, a szczególną potencjalną trudnością dla studentów jest konieczność konkurowania ze swoimi kolegami (Aburahma, Mohamed, 2015).

Do gier edukacyjnych należą gry biznesowe czy gry ekonomiczne, czasem określane też jako gry strategiczne. W ramach tych gier symuluje się działania całego przedsiębiorstwa lub jego części (Greene, 1960), a uczący się odgrywa rolę osoby prowadzącej własną firmę (Sørebø, Hæhre, 2012), podejmując sekwencję decyzji menedżerskich, odzwierciedlających funkcjonowanie firmy. Gracze otrzymują niepełną informację o grze i rynku, nie mają pełni wiedzy o sposobie, w jaki ich decyzje wpływają na ostateczny wynik gry (Jackson, 1959). Gra biznesowa jest metodą prób i błędów, gdyż możliwość analizy skutków swoich decyzji pozwala uczącym się na głębsze zrozumienie różnych aspektów zarządzania przedsiębiorstwem (Greene, 1960).

Gry biznesowe mają cztery zasadnicze elementy (Greene, 1960):

- zasady, które pokazują konieczne do podjęcia decyzje zarządcze i ich ograniczenia,

- strukturę, obejmującą zestaw parametrów gry i zależności między nimi,

- konkurencję, poprzez którą decyzje podejmowane przez jeden zespół graczy wpływają na wyniki uzyskiwane przez wszystkich uczestników,

- informację zwrotną po kolejnych rundach decyzyjnych rozgrywki.

Gry biznesowe wydają się mieć potencjał w edukacji przedsiębiorczej. Spełniają bowiem postulat związany z odniesieniem edukacji do rozwiązywania problemów 
realnego świata biznesowego, rozwijania nowych sposobów myślenia, zachowania czy zdolności, a ponadto sprzyjają zaangażowaniu w nie studentów.

Dodatkowo, wirtualne gry edukacyjne, w tym gry biznesowe, wydają się bardzo istotne z punktu widzenia charakterystyki osób cyfrowych z urodzenia. Wykorzystuje się w nich bowiem różne źródła przekazu informacji (obraz, kolor, dźwięk, film, tekst), pozwalają na pracę z grupach i komunikację poprzez różne media. Dają możliwość wdrożenia systemu natychmiastowych nagród i stanowią formę zabawy.

\section{Badanie możliwości rozwoju kompetencji przedsiębiorczych poprzez wirtualne gry strategiczne}

\section{Założenia badania}

Aby zrealizować cele artykułu i ocenić możliwość kształtowania kompetencji przedsiębiorczych poprzez edukację $z$ wykorzystaniem wirtualnych gier strategicznych, przeprowadzono rozgrywki tych gier wśród studentów z Estonii, Finlandii, Hiszpanii i Polski, a następnie zebrano ich opinie za pomocą kwestionariusza ankietowego. Rozgrywki były prowadzone na macierzystych uczelniach, wykorzystano ten sam silnik gry, jednak w każdym z krajów studenci rozgrywali odmienny scenariusz gry, przygotowany przez nauczycieli z ich macierzystej uczelni. W czasie rozgrywki studenci zostali podzieleni na zespoły 2-3-osobowe; każdy z zespołów zakładał i prowadził wirtualną firmę przez kilka rund decyzyjnych. Rozgrywki prowadzono w okresie od lutego do czerwca 2016 r.

Zebrano łącznie opinie 118 studentów, z czego 81,4\% stanowiły kobiety, a 18,6\% - mężczyźni. Wcześniejszego doświadczenia z grami edukacyjnymi nie miało 59,3\% badanych studentów (pozostałe 40,7\% takie doświadczenie miało). Z punktu widzenia narodowości, najliczniej reprezentowani byli Finowie (32,2\% respondentów), następnie Estończycy (28\% badanych), dalej Polacy (26,3\%), a najmniej liczną grupą byli Hiszpanie (13,6\%).

$\mathrm{Z}$ punktu widzenia oceny, na ile badani prezentowali pokolenie cyfrowych $z$ urodzenia, istotną wydaje się kwestia rozkładu wieku respondentów. Jeśli przyjąć za M. Prenskym (2001) graniczną datę urodzenia jako 1980 r., wówczas można stwierdzić, że 94,9\% należy do pokolenia cyfrowych z urodzenia. Z uwagi na fakt, że większość nie przekroczyła 23. roku życia, można przyjąć, że ponad $70 \%$ badanych należy do drugiego pokolenia cyfrowych z urodzenia. Podział wiekowy respondentów przedstawiono w tabeli 1. 
Tabela 1. Wiek badanych studentów

\begin{tabular}{|l|c|c|}
\hline \multicolumn{1}{|c|}{ Wiek repondentów } & Liczba respondentów & $\begin{array}{c}\text { Udział w grupie badawczej } \\
\text { (w \%) }\end{array}$ \\
\hline Do 18 lat & 6 & 5,1 \\
\hline 18-23 lat & 82 & 69,5 \\
\hline 24-34 lat & 24 & 20,3 \\
\hline Powyżej 35 lat & 6 & 5,1 \\
\hline
\end{tabular}

Źródło: opracowanie własne na podstawie wyników badania ankietowego.

W badaniu wykorzystano kwestionariusz ankietowy, w którym respondenci, po zakończonym kursie $\mathrm{z}$ wykorzystaniem wirtualnych gier strategicznych, zostali poproszeni o ocenę w skali 1-5 kompetencji, które w ich opinii są możliwe do kształtowania w procesie edukacji z wykorzystaniem tej metody. Ponieważ jednak w literaturze przedmiotu kompetencje przedsiębiorcze definiuje się na dość dużym poziomie abstrakcji, zdecydowano, że zostaną one nazwane w sposób jak najbardziej zrozumiały dla respondentów. Wykorzystano przy tym koncepcję T. Boyles (2012), wskazując konkretne kompetencje odnoszące się do kompetencji przedsiębiorczych i kompetencji XXI w. zgodnie z rysunkiem 1.

Aby odróżnić wpływ dotychczasowych doświadczeń z wirtualnymi grami edukacyjnymi na postrzeganie możliwości rozwoju kompetencji przedsiębiorczych, w kwestionariuszu ankietowym zadano również pytanie o posiadanie przez respondentów takowych. Z grupy 118 respondentów, 70 osób (59,3\% badanych) nie miało wcześniejszego doświadczenia z grami, natomiast pozostałe 48 osób (40,7\% badanych) takie doświadczenie miało.

Kolejną kwestią stawianą w badaniu było określenie wpływu tego, czy osoby uczące się są cyfrowymi z urodzenia, na możliwość kształtowania ich kompetencji. Najczęściej klasyfikowane są dane osoby jako cyfrowi z urodzenia lub cyfrowi imigranci na podstawie daty ich urodzenia (Prensky, 2001; Joiner i in., 2013; Kirk i in., 2015), jednakże w prezentowanym badaniu przyjęto inne kryterium, czyli opinie własne uczestników w odniesieniu do wykorzystania technologii ICT. Takie ujęcie wynikało $\mathrm{z}$ faktu, że grupa respondentów reprezentowała kraje o różnym czasie wprowadzenia do powszechnego użytku i stopniu nasilenia wykorzystania technologii ICT. Tak jak w przypadku Finlandii, jednego z krajów o największym rozwoju technologicznym, rok urodzenia 1980 można byłoby przyjąć jako bazowy do wyznaczania pokolenia cyfrowych, to w przypadku Polski i Estonii, z uwagi na przynależność do dawnego Bloku Wschodniego i przechodzenie transformacji systemowej, data ta może być wątpliwa. Aby uniknąć przedstawionych kontrowersji, 


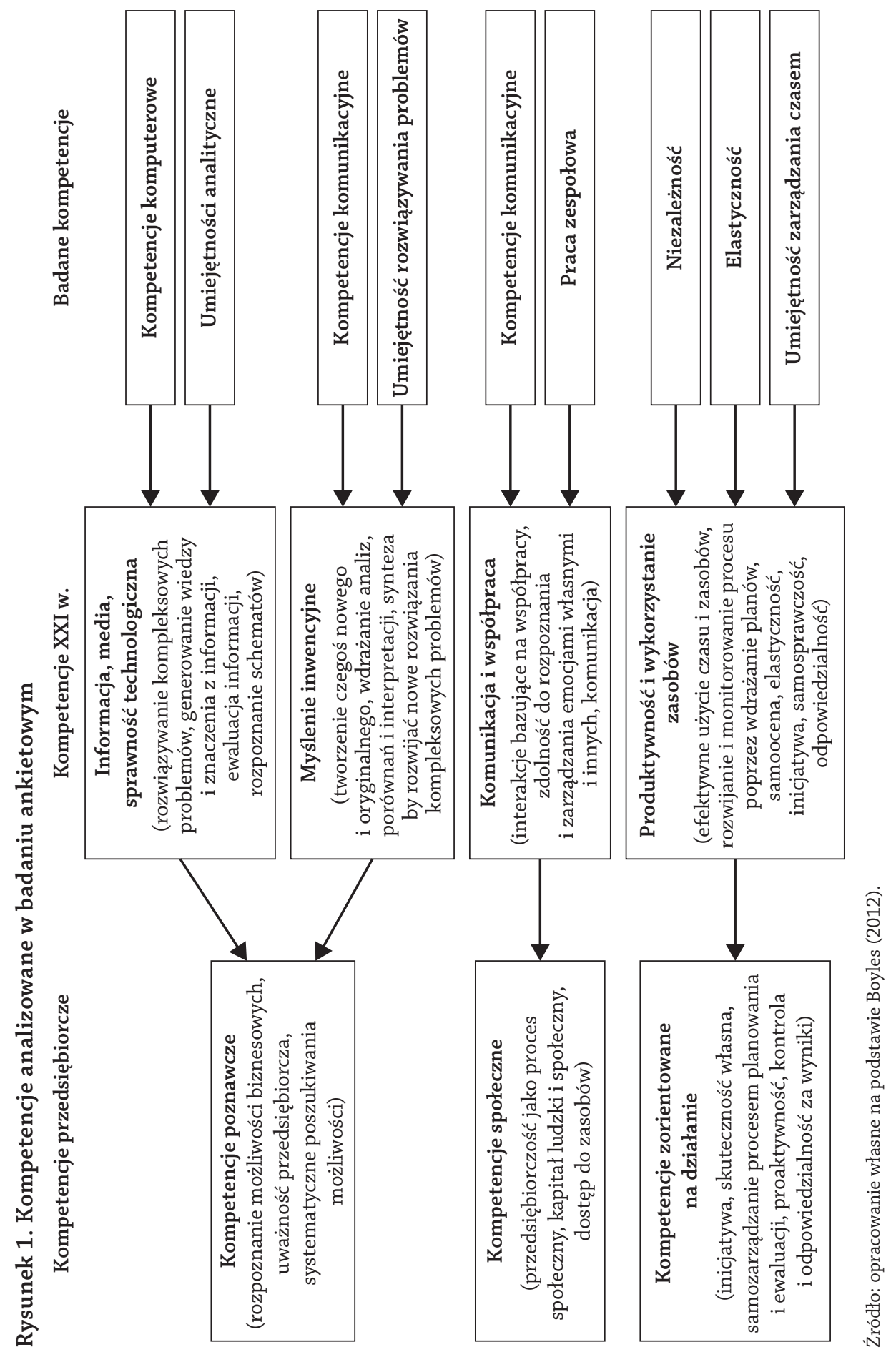


uczestnicy badania zostali poproszeni o odniesienie się w skali od 1 (całkowicie się nie zgadzam) do 5 (całkowicie się zgadzam) do trzech następujących twierdzeń:

1) „Lubię IT i swobodnie wykorzystuję różne media w moim codziennym życiu, studiach i pracy",

2) „Nienawidzę IT i raczej czuję się zakłopotany, używając nowego sprzętu elektronicznego. Prawdę mówiąc, zazwyczaj mam problem w przystosowaniu się do nowego środowiska elektronicznego",

3) „Wykorzystuję IT w mojej pracy, jednakże nie czuję się zbyt swobodnie z większością aplikacji”.

Pierwsze z tych stwierdzeń miało za zadanie identyfikować osoby, które czują się cyfrowe z urodzenia, drugie określenie odnosiło się do cyfrowych ignorantów, zaś ostatnie do cyfrowych imigrantów.

Przy konstrukcji kwestionariusza ankietowego wydawało się, że stwierdzenie pierwsze i drugie nawzajem się wykluczają. Analizując odpowiedzi, okazało się, że wprawdzie część ankietowanych, udzielając maksymalną liczbę punktów jednemu z tych dwóch stwierdzeń, drugiemu dawało najniższą. Jednakże najczęstsze sytuacje były takie, że pomimo najwyższej liczby punktów przydzielanych pierwszemu stwierdzeniu, równie dużo przydzielano kolejnym. W skali 1-5 średnia wartość punktów przydzielonych przez respondentów pierwszemu stwierdzeniu (cyfrowi $\mathrm{z}$ urodzenia) wyniosła 3,39 pkt, drugiemu stwierdzeniu (cyfrowi ignoranci) 2,14 pkt, a trzeciemu stwierdzeniu (cyfrowi imigranci) 2,75 pkt. Można zatem podejrzewać, iż stosunek współczesnych studentów do technologii ICT jest dość ambiwalentny.

Aby ten problem rozstrzygnąć, wobec każdego z ankietowanych wyznaczono wartość stopnia zaangażowania $\mathrm{w}$ technologie ICT w ten sposób, że od liczby punktów przypisanych stwierdzeniu odnoszącemu się do cyfrowych z urodzenia odejmowano liczbę punktów przypisanych stwierdzeniu odnoszącemu się do cyfrowych ignorantów, a punkty przypisane stwierdzeniu dotyczącemu cyfrowych imigrantów pomijano. Wyjaśniając sposób przeliczenia punktów na przykładzie, jeśli dany respondent był zdecydowanie cyfrowy z urodzenia, dając 5 pkt odpowiedzeniu stwierdzeniu i nie miał stosunku do ICT właściwego cyfrowemu ignorantowi, dając 1 pkt właściwemu stwierdzeniu, otrzymywał łącznie 4 pkt. Zatem każdy z badanych mógł otrzymać wartość swojego stosunku do bycia cyfrowym między 4 pkt a -4 pkt. Średnia wartość punktów dla całej zbiorowości wynosiła 1,25 pkt. Wziąwszy to pod uwagę, pogrupowano uczestników, zakładając, że cyfrowi z urodzenia mają lepszy niż przeciętny stosunek to technologii ICT, czyli wartość punktów wynosiła przynajmniej 2 lub więcej. Do tej grupy zakwalifikowano 45 osób (38,1\% badanych). Pozostałe osoby potraktowano łącznie jako niecyfrowych z urodzenia i przypisano do tej grupy 73 osoby (61,9\% respondentów). 


\section{Wyniki badania}

Uzyskane wyniki badania ankietowego, zaprezentowane w tabeli 2, zgodnie z przyjętym założeniem analizowano zarówno dla całej zbiorowości, jak i w podziale w zależności od posiadanych doświadczeń z wirtualnymi grami edukacyjnymi oraz od bycia cyfrowym z urodzenia.

Tabela 2. Możliwość rozwoju kompetencji przedsiębiorczych w czasie nauczania z wykorzystaniem wirtualnych gier strategicznych (w pkt)

\begin{tabular}{|c|c|c|c|c|c|}
\hline Rodzaje kompetencji & 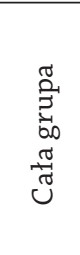 & 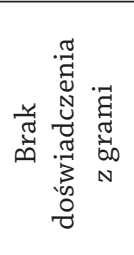 & 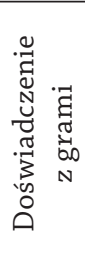 & 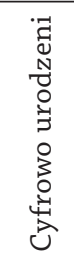 & 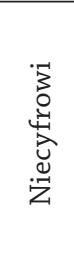 \\
\hline Kompetencje komunikacyjne & 3,81 & 3,91 & 3,67 & 4,00 & 3,70 \\
\hline Podejmowanie decyzji & 4,11 & 4,31 & 3,81 & 4,36 & 3,96 \\
\hline Praca zespołowa & 3,98 & 4,11 & 3,79 & 4,38 & 3,74 \\
\hline Elastyczność & 3,67 & 3,86 & 3,40 & 3,76 & 3,62 \\
\hline Umiejętności analityczne & 3,81 & 4,04 & 3,48 & 4,02 & 3,68 \\
\hline Niezależność & 3,12 & 3,30 & 2,85 & 2,98 & 3,21 \\
\hline $\begin{array}{l}\text { Umiejętność rozwiązywania } \\
\text { problemów }\end{array}$ & 3,92 & 4,10 & 3,65 & 4,22 & 3,73 \\
\hline $\begin{array}{l}\text { Umiejętność zarządzania } \\
\text { czasem }\end{array}$ & 3,42 & 3,60 & 3,17 & 3,58 & 3,33 \\
\hline Kompetencje komputerowe & 3,19 & 3,33 & 3,00 & 3,09 & 3,26 \\
\hline Średnia & 3,67 & 3,84 & 3,42 & 3,82 & 3,58 \\
\hline
\end{tabular}

Uwaga: oceny w skali od 1 do 5, gdzie: 1 - całkowity brak możliwości rozwoju kompetencji, zaś 5 - bardzo wysoka możliwość rozwoju kompetencji.

Źródło: opracowanie własne na podstawie wyników badania ankietowego.

Jak wskazują dane zaprezentowane w tabeli 2, cała grupa badawcza dość wysoko oceniła możliwość rozwoju kompetencji przedsiębiorczych dzięki nauczaniu $\mathrm{z}$ wykorzystaniem wirtualnych gier strategicznych. W skali od 1 do 5 , średnia ocena tych możliwości wynosi, zdaniem ankietowanych, 3,67 pkt. Najwyżej oceniono potencjał gier w kształtowaniu umiejętności podejmowania decyzji (4,11 pkt), pracy zespołowej (3,98 pkt) oraz umiejętności rozwiązywania 
problemów (3,92 pkt). W żadnej z badanych kompetencji średnia ocena respondentów nie była niższa niż 3,00 pkt.

Rozbijając grupę badawczą na dwie części w zależności od ich wcześniejszego doświadczenia z podobnymi grami edukacyjnymi, zaobserwowano, iż osoby, które nie miały wcześniej do czynienia z podobnymi grami edukacyjnymi, średnio oceniły wyżej możliwość kształtowania kompetencji przedsiębiorczych poprzez edukację z ich wykorzystaniem (średnia 3,84 pkt) niż osoby mające takie doświadczenie (średnia 3,42 pkt). Może to wynikać z faktu, iż wobec osób bez wcześniejszego doświadczenia zadział element nowości, przez co byli bardziej otwarci i pozytywnie nastawieni. Natomiast osoby, które wcześniej już się spotkały z podobnym narzędziem edukacyjnym, były do niego bardziej krytyczne i nastawione $\mathrm{z}$ dystansem.

Te dwie grupy nieco się różniły się w ocenie tych kompetencji, które w ich opinii w największym stopniu można kształcić poprzez wirtualne gry strategiczne. Osoby bez wcześniejszego doświadczenia $z$ analogicznymi grami, podobnie jak cała grupa, za kompetencje w największym stopniu możliwe do rozwijania poprzez gry strategiczne wskazały umiejętności podejmowania decyzji (4,31 pkt), pracy zespołowej $(4,11 \mathrm{pkt})$ oraz umiejętności rozwiązywania problemów $(4,10 \mathrm{pkt})$. Natomiast osoby mające stosowne doświadczenie uznały, że w największym stopniu poprzez gry można rozwijać zdolność do podejmowania decyzji $(3,81$ pkt) i pracy zespołowej (3,79 pkt) oraz umiejętności komunikacyjne (3,67 pkt). Relatywnie wysoką ocenę rozwojowi umiejętności komunikacyjnych w grupie respondentów mających doświadczenie z grami można tłumaczyć ich nieformalnymi opiniami formułowanymi w rozmowach. Ich wcześniejsze doświadczenia wskazywały, jak duże znaczenie dla skuteczności działań ma spójna praca całego zespołu, która jest niemożliwa bez sprawnej komunikacji. Stąd też dużo uwagi przyłożyli oni do porozumienia w grupie, dzięki czemu wyżej ocenili rozwój kompetencji w tym obszarze.

Patrząc na oceny możliwości rozwoju kompetencji przez pryzmat przynależności stosunku do technologii ICT, można zauważyć, iż osoby cyfrowe z urodzenia oceniły średnie możliwości kształtowania kompetencji przedsiębiorczych wyżej (3,82 pkt) niż niecyfrowi (3,58 pkt). Wystąpiły również nieznaczne różnice w trzech najwyżej ocenionych kompetencjach. Cyfrowi z urodzenia najwyżej ocenili możliwość rozwoju umiejętności pracy w zespole (4,38 pkt), podejmowania decyzji (4,36 pkt) i rozwiązywania problemów (4,22pkt). Ocena możliwości rozwoju pracy zespołowej została przez tę grupę najwyżej oceniona spośród wszystkich wyróżnionych grup, co może poświadczać ich charakterystykę jako osób, dla których kontakty grupowe są ważniejsze niż kontakty indywidualne. Osoby określone jako niecyfrowe najwyżej oceniły możliwość wykorzystania gier 
w kształtowaniu umiejętności podejmowania decyzji (3,96 pkt), pracy zespołowej (3,74 pkt) oraz umiejętności rozwiązywania problemów (3,73 pkt).

\section{Podsumowanie}

W artykule przedstawiono możliwości rozwoju kompetencji przedsiębiorczych dzięki edukacji z wykorzystaniem wirtualnej gry strategicznej. Na podstawie badania przeprowadzonego wśród studentów z Polski, Finlandii, Hiszpanii i Estonii określono możliwość rozwoju kompetencji poznawczych (zdolność do podejmowania decyzji, zdolności analityczne, rozwiązywania problemów, kompetencje komputerowe), społecznych (umiejętności komunikacyjne, umiejętność pracy zespołowej) i zorientowanych na działanie (niezależność, elastyczność, zarządzanie czasem).

Badani wysoko ocenili możliwości rozwoju kompetencji przedsiębiorczych dzięki edukacji z wykorzystaniem wirtualnych gier strategicznych. Szczególne uznanie zyskała możliwość rozwoju zdolności do podejmowania decyzji oraz umiejętności pracy grupowej i rozwiązywania problemów. Zatem są to kompetencje z grupy kompetencji poznawczych i społecznych, raczej szeroko rozumiane jako kompetencje osoby przedsiębiorczej, a nie wąsko rozumiane jako kompetencje związane z samodzielnym prowadzeniem własnego przedsiębiorstwa.

Równocześnie wystąpiły pewne różnice w ocenach osób mających i niemających wcześniejszego doświadczenia z grami edukacyjnymi. Osoby wcześniej biorące udział w nauczaniu z wykorzystaniem analogicznych gier były bardziej krytyczne i niżej oceniły możliwość rozwoju kompetencji przedsiębiorczych. Obie grupy doceniły możliwość kształtowania kompetencji związanych z podejmowaniem decyzji i pracą zespołową, jednak osoby doświadczone w tej materii równie wysoko oceniły możliwość rozwoju umiejętności komunikacyjnych poprzez edukację z wykorzystaniem gier.

Zgodnie z drugim przyjętym podziałem, osoby cyfrowe z urodzenia wyżej oceniły możliwość kształtowania kompetencji przedsiębiorczych dzięki edukacji z wykorzystaniem wirtualnych gier strategicznych niż osoby niecyfrowe. Obie grupy jako najistotniejsze rozwijane kompetencje uznały wprawdzie te same umiejętności (decyzyjność, praca zespołowa, rozwiązywanie problemów), jednak dla cyfrowych z urodzenia, jako dla jedynej z wyróżnionych grup, najważniejsza była sposobność do rozwijania zdolności do pracy w zespole.

Wyniki badania wskazują zatem na pozytywne możliwości rozwoju kompetencji przedsiębiorczych dzięki nauczaniu z wykorzystaniem wirtualnych gier strategicznych. Wydaje się, iż gry te rozwijają w większym stopniu ogólne kompetencje 
osób przedsiębiorczych, a nie wyłącznie kompetencje do działania jako przedsiębiorca. Mają zatem walory dość uniwersalne.

Wydaje się, że istotna w tej metodzie dydaktycznej jest różnorodność wykorzystywanych gier, dzięki czemu można zachować efekt nowości tej metody, istotny dla osób, które wcześniej już się z tym narzędziem dydaktycznym spotkały.

\section{Bibliografia}

Aburahma, M.H., Mohamed, H.M. (2015). Educational Games as a Teaching Tool in Pharmacy Curriculum. American Journal of Pharmaceutical Education, 79(4), 1-9.

Balan, P., Metcalfe, M. (2012). Identifying teaching methods that engage entrepreneurship students. Education and Training, 54(5), 368-384.

Boyles, T. (2012). 21 ${ }^{\text {st }}$ Century Knowledge, Skills, and Abilities and Entrepreneurial Competencies: A Model for Undergraduate Entrepreneurship Education. Journal of Entrepreneurship Education, 15, 41-55.

Chaves, H.V., Maia Filho, O.N., Melo, A.S.E. (2016). Education in Times Net Generation: How Digital Immigrants Can Teach Digital Natives? HOLOS, 32(2), 347-356.

Gaweł, A., Wach-Kąkolewicz, A. (2016). Konstruktywizm edukacyjny w nauczaniu przedsiębiorczości metodą gier elektronicznych. Horyzonty Wychowania, 15(34), 87-102.

Greene, J.R. (1960). Business Gaming for Marketing Decisions. Journal of Marketing, 27(1), 21-25.

Heinonen, J., Poikkijoki, S.-A. (2006). An entrepreneurial-directed approach to entrepreneurship education: Mission impossible? Journal of Management Development, 25(1), 80-94.

Jackson, J.R. (1959). Learning from Experience in Business Decision Games. California Management Review, 1(2), 92-107.

Joiner, R., Gavin, J., Brosnan, M., Cromby, J., Gregory, H., Guiller, J., Maras, P., Moon, A. (2013). Comparing First and Second Generation Digital Natives' Internet Use, Internet Anxiety, and Internet Identification. Cyberpsychology, Behavior, and Social Networking, 16(7), 549-552.

Kąkolewicz, M. (2011). Uczenie się jako konstruowanie wiedzy. Świadomość, qualia i technologie informacyjne. Poznań: Wydawnictwo Naukowe UAM.

Kirk, C.P., Chiagouris, L., Lala, V., Thomas, J.E. (2015). How Do Digital Natives and Digital Immigrants Respond Differently to Interactivity Online? A Model for Predicting Consumer Attitudes and Intentions to Use Digital Information Products. Journal of Advertising Research, 55(1), 81-94.

Lans, T., Hulsink, W., Baert, H., Mulder, M. (2008). Entrepreneurship Education and Training in a Small Business Context: Insights from the Competence-Based Approach. Journal of Enterprising Culture, 16(4), 363-383. 
Neumann, C. (2016). Teaching Digital Natives: Promoting Information Literacy and Addressing Instructional Challenges. Reading Improvement, 53(3), 101-106.

Piróg, D. (2015). Kompetencje z zakresu przedsiębiorczości: rozważania teoretyczne i ich ilustracje w obszarze szkolnictwa wyższego. Przedsiębiorczość - Edukacja, 11, 364-376.

Prensky, M. (2001). Digital Natives, Digital Immigrants. On the Horizon (MCB University Press), 9(5), 1-6.

Rasmussen, E., Mosey, S., Wright, M. (2015). The transformation of network ties to develop entrepreneurial competencies for university spin-offs. Entrepreneurship \& Regional Development, 27(7-8), 430-457.

Sørebø, O., Hæhre, R. (2012). Investigating Students' Perceived Discipline Relevance Subsequent to Playing Educational Computer Games: A Personal Interest and Self-Determination Theory Approach. Scandinavian Journal of Educational Research, 56(4), 345-362.

Tan, S.S., Ng, C.K.F. (2006). A problem-based learning approach to entrepreneurship education. Education and Training, 48(6), 416-428.

Wach, K. (2016). Edukacja przedsiębiorcza: analiza bibliometryczna polskiego piśmiennictwa. Horyzonty Wychowania, 15(34), 11-26.

\section{Summary}

\section{Development of Entrepreneurial Competencies through Learning with the Use of Virtual Strategic Games}

The aim of the paper is to evaluate the possibilities of entrepreneurial competencies development thanks to the use of innovative teaching tools such as virtual strategic games. This tool puts learners in the position of entrepreneurs who then establish virtual companies and run them during several decision rounds, competing with other companies. This form of education stimulates the management of a company in the virtual environment. The research was conducted among students from Poland, Finland, Spain and Estonia, who attended the virtual strategic game. After the end of the game, they were asked to assess the possible competencies to be developed thanks to participation in the game. According to respondents, the strategic virtual games allow players to develop most their decision-making skills, team work and problem-solving skills. It can be seen that the possibilities of competencies development depend on the previous experience of students with virtual educational games and on the degree to which they feel they are digital natives. 
Keywords: entrepreneurial competencies, virtual strategic games, digital natives, entrepreneurial education, gamification

\section{Prof. dr hab. Aleksandra Gaweł}

Profesor nauk ekonomicznych, pracownik Katedry Konkurencyjności Międzynarodowej na Wydziale Gospodarki Międzynarodowej Uniwersytetu Ekonomicznego w Poznaniu. Wykładowca takich przedmiotów, jak m.in. mikroekonomia, przedsiębiorczość, wirtualne gry strategiczne. Autor lub współautor ponad 100 publikacji, głównie z zakresu przedsiębiorczości, nauczania przedsiębiorczości, wirtualnych gier strategicznych, cyklu koniunkturalnego, umiędzynarodowienia przedsiębiorstw. Koordynator i/lub uczestnik wielu projektów dydaktycznych i naukowych, głównie projektów międzynarodowych. Członek Komitetu Redakcyjnego, były Redaktor Naczelny i twórca miesięcznika naukowego STUDIA OECONOMICA POSNANIENSIA, wydawanego przez Uniwersytet Ekonomiczny w Poznaniu. Recenzent krajowych i zagranicznych czasopism naukowych. Członek zespołu tworzącego i rozwijającego wirtualne gry strategiczne na UEP. 